\title{
Composition of the essential oil from the leaves of tree domestic varieties and one wild variety of the guava plant (Psidium guajava L., Myrtaceae)
}

\author{
Rafaela Karin de Lima, ${ }^{* 1}$ Maria das Graças Cardoso, ${ }^{1}$ Milene Aparecida Andrade, ${ }^{1}$ \\ Evandro Afonso Nascimento, ${ }^{2}$ Sérgio Antônio Lemos de Morais, ${ }^{2}$ David Lee Nelson ${ }^{3}$
}

\author{
${ }^{1}$ Departamento de Química, Universidade Federal de Lavras, Campus Universitário, Caixa Postal 3037, \\ 37200-000 Lavras-MG, Brazil \\ ${ }_{2}^{2}$ Instituto de Química, Universidade Federal de Uberlândia, Av. Engenheiro Diniz, 1178, Caixa Postal 593, \\ 38.400-902 Uberlândia-MG, Brazil \\ ${ }^{3}$ Departamento de Alimentos, Faculdade de Farmácia, Universidade Federal de Minas Gerais, Av. Antônio Carlos, \\ 6627, 31270-901 Belo Horizonte-MG, Brazil.
}

\begin{abstract}
RESUMO: "Avaliação dos constituintes dos óleos essenciais de folhas de goiabeira (Psidium guajava L., Myrtaceae) de três cultivares e da planta silvestre". Os óleos essenciais de folhas de goiabeira Psidium guajava L. de três diferentes cultivares (Paluma, Século XXI e Pedro Sato) e da planta silvestre foram analisados a fim de comparar os seus constituintes. O óleo essencial foi obtido por hidrodestilação em aparelho de Clevenger modificado. Para a caracterização e quantificação dos compostos presentes por CG-EM e CG respectivamente. Os resultados mostraram que os três óleos essenciais analisados apresentam inúmeras substâncias em comum com a predominância do 1,8-cineol. O óleo essencial da cultivar Paluma se difere dos demais devido a alta concentração de 1,8-cineol $(42,68 \%)$ e do $\alpha$-terpineol $(38,68 \%)$. No óleo essencial da cultivar Século XXI observase a presença do 1,8 cineol $(18,83 \%)$, trans-carifileno $(12,08 \%)$ e o selin-11-en-4- $\alpha$-ol $(20,98 \%)$ como majoritários, enquanto que a cultivar Pedro Sato e a planta silvestre apresentaram com o 1,8 cineol com $(17,68 \%)$ e $(12,83 \%)$, oxido de cariofileno $(9,34 \%)$ e $(9,09 \%)$ e o selin-11-en- $4-\alpha-o l$ com $(21,46 \%)$ e $(22,19 \%)$, respectivamente.
\end{abstract}

Unitermos: Hidrodestilação, goiabeira, 1,8-cineol, Psidium guajava, Myrtaceae.

\begin{abstract}
The compositions of the essential oils from the leaves of three domestic varieties of the guava tree Psidium guajava L. (Paluma, Século XXI and Pedro Sato) and of one wild variety were compared. Essential oils were extracted by steam distillation, the components were identified by gas chromatography coupled to mass spectrometry GC-MS, and the apparent concentrations were determined by gas chromatography with a flame ionization detector. The results demonstrated that the three essential oils contained many common substances with a prevalence of 1,8-cineole, whereas the essential oil of the Paluma variety contained 1,8 -cineole $(42.68 \%)$ as the major constituent, as well as $\alpha$-terpineol (38.68\%). The principal components of the essential oil of the Século XXI variety were 1,8-cineole (18.83\%), trans-caryophyllene (12.08\%), and selin-11-en-4- $\alpha$ ol $(20.98 \%)$, while those of the Pedro Sato variety and of the wild plant were 1,8 -cineole $(17.68 \%)$ and $(12.83 \%)$, caryophyllene oxide $(9.34 \%)$ and $(9.09 \%)$, and selin-11-en-4- $\alpha$-ol $(21.46 \%)$ and $(22.19 \%)$, respectively.
\end{abstract}

Keywords: Hydrodistillation, guava tree, 1,8-cineole, Psidium guajava, Myrtaceae.

\section{INTRODUCTION}

The guava plant is of the Myrtaceae family and originates from tropical regions of Central and South America. There exist approximately three hundred twenty four known species in these regions, distributed and cultivated mainly in tropical and subtropical countries. Of the genus Psidium, the most important species is classified as Psidium guajava L., Myrtaceae. The most widespread varieties are Paluma, Pedro Sato, Ogawa and Kumagai, and the Brazilian production is concentrated in the states of São Paulo and Pernambuco (Pereira, 1995; Manica et al., 2000).

The tea made from the leaves is well known, being used for cramps and diarrhoea; many studies have been performed in this respect (Lutterodt, 1989; Almeida 
et al., 1995; Lozoya et al., 2002). The leaves were observed to contain amino acids, triterpenes and steroids, acids, phenols, saponins and carotenes. Volatile acids [(E)-cinnamic acid and (Z)-3-hexenoic acid], fatty acids, and the essential oil were also encountered (Opute, 1978; Cuellar et al., 1984; Idstein et al., 1985; Mercadante et al., 1999).

The extracts of the leaves from $P$. guajava present numerous antimicrobial activities against microorganisms such as Candida albicans and such bacteria as Staphylococcus aureus, Salmonella enteritidis, and Bacillus cereus. They also possess antioxidant activity as a result of the presence of vitamins, carotenoids, polyphenols and, principally, ascorbic acid (Nogueira et al., 1978; Nascimento et al., 2000; Qian \& Nihorimbere, 2004).

The essential oil from the guava leaves has been found to possess many compounds, 1,8-cineole and trans-caryophyllene being the most frequently encountered ( $\mathrm{Li}$ et al., 1999; Chen et al., 2007; Cole \& Setzer, 2007). Pharmacological studies reported important anti-proliferation, anti-oxidant and antimicrobial activities (Manosroi et al., 2006; Sacchetti et al., 2005).

The chemical composition of the essential oils can vary widely in different regions, principally because of environmental factors, as well as genetic factors that can induce modifications in the secondary metabolism of the plant (Taiz \& Zeiger, 1991). Therefore, the present study sought to characterize and compare the contents of the essential oils from the leaves of the Paluma, Pedro Sato and Século XXI varieties and from a wild variety of the guava plant (Psidium guajava L.).

\section{MATERIAL AND METHODS}

\section{Plant material}

Guava plant leaves from the Pedro Sato, Paluma and Século XXI varieties and from a wild variety were collected in the region of Lavras, Minas Gerais, Brazil. The collection was performed in the morning at approximately 7 am on sunny days, without rain, during March, 2008. Exsiccates of these plants were prepared and sent to the Herbário ESAL of the Departamento de Biologia of the Universidade Federal de Lavras for confirmation of the species, whose registry number is 20.207.

\section{Extraction of the essential oil}

The essential oil was extracted in the Laboratório de Química Orgânica of the Universidade Federal de Lavras. The leaves were chopped and weighed (300 g). The essential oils were obtained by steam distillation employing a modified Clevenger apparatus. The extraction was performed during a period of $2.5 \mathrm{~h}$. The organic and aqueous phases of the distillate were separated by centrifugation (965.36 $\mathrm{g}$ for $5 \mathrm{~min}$ ). The oil was removed with a micropipette and stored protected from the light (Castro et al., 2006).

\section{Humidity test}

The humidity of the leaves was determined simultaneously with the extraction of the essential oil. A mixture of $5.0 \mathrm{~g}$ of chopped leaves and $80 \mathrm{~mL}$ of cyclohexane were heated under reflux according to the method described by Pimentel et al. (2006) to determine the concentration of the oil (w/w) in the dried plant. The oil and humidity contents of the dried plant were determined in triplicate.

\section{Composition and identification of the constituents of the essential oils}

The identification of the constituents of the essential oils was performed in the Laboratório de Química de Produtos Naturais of the Universidade Federal de Uberlândia. The oil was submitted to gas chromatography coupled with mass spectrometry (GC/MS) on a Shimadzu, model CG 17A chromatograph equipped with a model QP 5000 mass detector and a $30 \mathrm{~m}$ by $0.25 \mathrm{~mm}$ fused silica capillary column containing DB5, with helium as the carrier gas. The injector temperature was $220{ }^{\circ} \mathrm{C}$ and the detector temperature was $240{ }^{\circ} \mathrm{C}$. The oven temperature was programmed from 60 to $240{ }^{\circ} \mathrm{C}$ at $3{ }^{\circ} \mathrm{C} / \mathrm{min}$. The compounds were identified by comparison of the mass spectra with spectra from the library (Wiley 140) and by the Kovat's Index (Adams, 1995).

The assessment of the quantities of constituents in the essential oil was performed using a Shimadzu GC 17A gas chromatograph equipped with a flame ionization detector and a DB5 capillary column under the following operational conditions: the column temperature was programmed from 40 to $240{ }^{\circ} \mathrm{C}$; injector temperature, 220 ${ }^{\circ} \mathrm{C}$, detector temperature, $240{ }^{\circ} \mathrm{C}$, carrier gas, nitrogen $(2.2$ mL.min-1), split rate, 1:10; volume injected, $1 \mu \mathrm{L}(1 \%$ solution in dichloromethane) and column pressure, 115 $\mathrm{kPa}$. The quantification of each constituent was obtained through normalization of areas (\%).

\section{RESULTS AND DISCUSSION}

The essential oils from guava leaves of Paluma, Pedro Sato, and Século XXI varieties and from wild plants furnished almost the same yields. Eighteen monoterpenes and sesquiterpenes were identified and are presented in Table 1 with their respective concentrations (\%) and Kovats indexes. The structural formulas of some of these compounds are depicted in Figure 1.

The chemical constitution of the essential oil from the wild plant is very similar to that of the Pedro Sato and Século XXI varieties, differing in the concentration 
of the constituents and in the presence of $\beta$-bisabolol. Moreover, the composition of the essential oil from the Paluma variety is different. There is a high concentration of 1,8 -cineole $(42.68 \%)$ and $\alpha$-terpineol $(38.68 \%)$, and the presence of cis-sabinene hydrate (1.65\%), terpin-4-ol $(1.65 \%)$ and borneol (1.06\%) was also observed.

The essential oil from guava leaves characterized in the state of Ceará presented several compounds in common with the oil under study, such as $\alpha$-terpineol, trans-caryophyllene, humulene and $\alpha$-borneol. (Craveiro et al., 1891; Santos et al., 1998). Silva et al. (2003) observed that the major constituents of guava essential oil from the state of Pará were $\alpha$-pinene (23.9\%), 1,8 cineole (21.4\%) and $\beta$-bisabolol (9.2\%).

The essential oil of the Século XXI variety contained the highest concentration of trans-caryophyllene $(12.08 \%)$ among the four varieties. This compound is one of the main constituents of the essential oil from guava leaves from various countries such as China $(18.8 \%)$, Cuba (21.6\%), Nigeria (21.3\%) and Taiwan (27.7\%) (Li et al., 1999; Pino et al., 2001; Ogunwande et al., 2003; Chen et al., 2007).
Some compounds encountered in the essential oil from guava leaves possess important biological activities and have proven medical uses. Trans-caryophyllene has espasmolític activity and local anesthetic and antiinflammatory activities, $\alpha$-terpineol has insecticidal activity against several insects, and 1,8-cineole acts as an expectorant, analgesic and antiseptic (Prates et al., 1998; Lee et al., 2004; Simões \& Spitzer, 2004).

\section{CONCLUSION}

There was a greater variation in the constituents of the essential oil from guava leaves of the Paloma variety as a result of the high concentration of 1,8 cineole (42.68\%) and $\alpha$-terpineol $(38.68 \%)$. The major components of the essential oil of the Seculo XXI variety were 1,8-cineole (18.83\%), trans-caryophyllene (12.08\%) and selin-11-en$4-\alpha$-ol $(20.98 \%)$ while those of the wild plant and the Pedro Sato variety were 1,8 -cineole $(17.68 \%)$ and $(12.83 \%)$, caryophyllene oxide $(9.34 \%)$ and $(9.09 \%)$ and selin-11en-4- $\alpha$-ol $(21.46 \%)$ and $(22.19 \%)$, respectively.

Table 1. Percentage compositions and Kovat's indices of the components of the essential oils from three domestic and one wild variety of $P$. guajava.

\begin{tabular}{|c|c|c|c|c|c|c|}
\hline \multirow[b]{2}{*}{ Compound } & \multicolumn{3}{|c|}{ Domestic Variety } & \multirow[b]{2}{*}{ Wild Variety } & \multirow[b]{2}{*}{ IKcalc } & \multirow[b]{2}{*}{ IKtab } \\
\hline & Paluma & Pedro Sato & $\begin{array}{l}\text { Século } \\
\text { XXI }\end{array}$ & & & \\
\hline benzaldehyde & & 2.32 & 2.69 & 1.59 & 0959 & 0961 \\
\hline 1,8 -cineole & 42.68 & 17.68 & 18.83 & 12.83 & 1032 & 1033 \\
\hline cis-ocimene & & 1.77 & 0.92 & 1.83 & 1038 & 1040 \\
\hline trans-sabinene hidrato & 1.65 & & & & 1097 & 1097 \\
\hline borneol & 1.06 & & & & 1161 & 1165 \\
\hline terpin-4-ol & 3.94 & & & & 1173 & 1177 \\
\hline$\alpha$-terpineol & 38.68 & 2.79 & 3.06 & 0.86 & 1191 & 1189 \\
\hline trans-caryophyllene & & 8.24 & 12.08 & 8.89 & 1420 & 1418 \\
\hline$\alpha$-humulene & & 1.46 & 2.07 & 1.51 & 1452 & 1454 \\
\hline guaiene & & 3.91 & 4.50 & 6.74 & 1487 & 1490 \\
\hline$\alpha$-selinene & & 3.55 & 4.20 & 5.79 & 1495 & 1494 \\
\hline trans-nerolidol & 0.36 & 3.34 & 8.19 & 4.65 & 1569 & 1564 \\
\hline caryophyllene oxide & 2.26 & 9.34 & 6.89 & 9.09 & 1587 & 1581 \\
\hline humulene epoxide & 0.37 & 2.33 & 2.23 & 2.46 & 1610 & 1606 \\
\hline cadinol & 0.38 & 7.28 & 1.16 & 8.18 & 1637 & 1640 \\
\hline selin-11-en-4- $\alpha$-ol & & 21.46 & 20.98 & 22.19 & 1662 & 1652 \\
\hline $\begin{array}{l}\text { 14-hydroxy-9-epi-(E)- } \\
\text { caryophyllene }\end{array}$ & & 2.00 & 0.81 & 2.01 & 1668 & 1664 \\
\hline$\beta$-bisabolol & & & & 0.91 & 1683 & 1671 \\
\hline yield $(\% \mathrm{w} / \mathrm{w})$ & 0.09 & 0.10 & 0.11 & 0.11 & & \\
\hline
\end{tabular}

IKcalc-calculated Kovat's index; IKtab-tabulated Kovat's index (Adams, 1995). 


\section{REFERENCES}

Adams RP 1995. Identification of essential oil components by gas chromatography/mass spectroscopy. Ilinois: Allured Publishing Corporation.

Almeida CE, Karnikowski MG, Foleto R, Baldisserotto B 1995. Analysis of antidiarrhoeic effect of plants used in popular medicine. Rev Saude Publica 29: 428-33.

Castro DP, Cardoso MG, Moraes JC, Santos NM, Baliza DP 2006. Não preferência de Spodoptera frugiperda (Lepidoptera: Noctuidae) por óleos essenciais de Achillea millefolium L. e Thymus vulgaris L.. Rev Bras Pl Med 8: 27-32.

Chen HC, Sheu MJ, Lin LY, Wu CM 2007. Chemical composition of the leaf essential oil of Psidium guajava L. from Taiwan. J Essent Oil Res 19: 345-347.

Cole RA, Setzer WN 2007. Chemical composition of the leaf essential oil of Psidium guajava from Monteverde, Costa Rica. J Essent Oil-Bear Plants 10: 365-373.

Craveiro AA, Fernandes AG, Andrade CHS, Matos FJA, Alencar JW, Machado MIL 1981. Óleos essenciais de plantas do nordeste. Fortaleza: UFC.

Cuellar AC, Lara RA, Zayas JP 1984. Psidium guajava L. Tamizaje fitoquímico y estudio del aceite esencial. Rev Cubana Farm 18: 92-99.

Idstein H, Bauer C, Schreier P 1985. Volatile acids in tropical fruits: cherimoya (Annona cherimolia Mill.), guava (Psidium guajava L.), mango (Mangifera indica L., var. Alphonso), papaya (Carica papaya L.). Z Lebensm Unters For 180: 394-397.

Lee BH, Annis PC, Tumaalii F, Choi WS 2004. Fumigant toxicity of essential oils from the Myrtaceae family and 1,8cineole against 3 major stored-grain insects. $J$ Stored Prod Res 40: 553-564.

Li J, Chen F, Luo J 1999. GC-MS analysis of essential oil from the leaves of Psidium guajava. Zhong Yao Cai 22: 7880 .

Lozoya X, Reyes-Morales H, Chávez-Soto MA, Martínez-García MC, Soto-González Y, Doubova SV 2002. Intestinal anti-spasmodic effect of a phytodrug of Psidium guajava folia in the treatment of acute diarrheic disease. $J$ Ethnopharmacol 83: 19-24.

Lutterodt GD 1989. Inhibition of gastrointestinal release of acetylcholine by quercetin as a possible mode of action of Psidium guajava leaf extracts in the treatment of acute diarrhoeal disease. J Ethnopharmacol 25: 235-247.

Manica I, Icuma IM, Junqueira NTV, Salvador JO, Moreira A, Malavolta E 2000. Goiaba. Fruticultura Tropical 6: Porto Alegre: Cinco Continentes Editora.

Manosroi J, Dhumtanom P, Manosroi A 2006. Anti-proliferative activity of essential oil extracted from Thai medicinal plants on KB and P388 cell lines. Cancer Lett 235: 114120.

Mercadante AZ, Steck A, Pfander H 1999. Carotenoids from guava (Psidium guajava L.): isolation and structure elucidation. J Agric Food Chem 47: 145-15.

Nascimento GGF, Locatelli J, Freitas PC, Silva GL 2000.
Antibacterial activity of plant extracts and phytochemicals on antibiotic-resistant bactéria. Braz J Microbiol 31: 247 256

Nogueira JN, Soybihe Sobrinho J, Vencosvsk YR, Fonseca H 1978. Effect of storage on the levels of ascorbic acid and beta-carotene in freeze dried red guava (Psidium guajava L.). Arch Latinoam Nutr 28: 363-377.

Ogunwande IA, Olawore NO, Adeleke KA, Ekundayo O, Koenig WA 2003. Chemical composition of the leaf volatile oil of Psidium guajava L. growing in Nigeria. Flavor Frag J 18: 136-138.

Opute FI 1978. The component fatty acids of Psidium guajava seed fats. J Sci Food Agric 29: 737-738.

Pereira FM 1995. Cultura da Goiabeira. Jaboticabal: FUNEP.

Pimentel FA, Cardoso MG, Salgado APSP, Aguiar PM, Silva VF, Morais AR, Nelson DLA 2006. Convenient method for the determination of moisture in aromatic plants. Quim Nova 29: 373-375.

Pino JÁ, Aguero J, Marbot R, Fuentes V 2001. Leaf oil of Psidium guajava L. from Cuba. J Essent Oil Res 31: 61-62.

Prates HT, Santos JP, Waquil JM, Fabris JD, Oliveira AB, Foster JE 1998. Insecticidal Activity of Monoterpenes Against Rhyzopertha dominica (F.) and Tribolium castaneum (Herbs). J Stored Prod Res 34: 243-249.

Qian H, Nihorimbere V 2004. Antioxidant power of phytochemicals from Psidium guajava leaf. $J$ Zhejiang Univ Sci 5: 676-683.

Sacchetti G, Maietti S, Muzzoli MV, Scaglianti M, Manfredini S, Radice M, Bruni R 2005. Comparative evaluation of 11 essential oils of different origin as functional antioxidants, antiradicals and antimicrobials in foods. Food Chem 91: 621-632.

Santos FA, Rao VSN, Silveira ER 1998. Investigations on the antinociceptive effects Psidium guajava leaf essential oil and its major constituents. Phytother Res 12: 24-27.

Silva JD, Luz AIR, Silva MHL, Andrade EHA, Zoghbi MGB, Maia JGS 2003. Essential oils of the leaves and stems of four Psidium spp. Flavor Frag J 18: 240-243.

Simões CM, Spitzer V 2004. Óleos Voláteis. In: Farmacognosia: da planta ao medicamento. 5. ed. Porto Alegre (RS): Ed. da UFSC, p. 467-495.

Taiz L, Zeiger E 1991. Surface protection and secondary defense compound. In: Plant Physiology. California: Benjamin/ Cumming, p. 318-345. 